\title{
La imagen-barroco. Introducción al cine de Andrés Di Tella*
}

\section{Resumen}

El presente artículo se centra en el estudio de las tácticas de creación del documentalista argentino Andrés Di Tella. Dichas tácticas tienen en común la lectura desviada de archivos visuales, adoptando elementos del collage, el ready-made y el found footage. La metodología que planteamos establece como marco de referencia los procesos de mestizaje e hibridación del barroco Latinoaméricano y europeo, de cara a determinar los modos de plegamiento y síntesis que operan en sus películas. Así, los resultados de nuestra investigación revelan cómo las tácticas de cada película de Di Tella - la reconstrucción de la reconstrucción en Reconstruyen crimen de la modelo (1990); la historia de la historia en Montoneros, una historia (1995); el arte del arte en Macedonio Fernández (1995); la imagen de la no-imagen en La televisión y yo (2002); la otredad del yo en Fotografías (2007); el archivo del archivo en El país del diablo (2008); la totalidad de las imágenes en Hachazos (2011) y la totalidad de palabras en 327 cuadernos (2015) - se construyen a partir de una pluralidad de estragias de apropiación y recontextualización que revelan una multiplicidad de maneras de expresar lo que hemos denominado la imagen-barroco.

\author{
Miguel Alfonso Bouhaben \\ Doctor en Comunicación \\ Audiovisual \\ Profesor Titular Facultad de Arte, \\ Diseño y Comunicación Audiovisual \\ Escuela Superior Politécnica del \\ Litoral \\ Guayaquil, Ecuador \\ Correo electrónico: \\ malfonso@espol.edu.ec \\ ๑ orcid.org/0000-0002-4439-4596 \\ Google Scholar
}

Recibido: abril 05 de 2019

Aprobado: noviembre 03 de 2020

Palabras clave:

Archivos audiovisuales, Barroco, Cine documental, Hibridaciones estéticas, Pliegue.

\footnotetext{
* Este trabajo es uno de los resultados investigativos derivados de la estancia de investigación realizada en el Instituto de Artes del Espectáculo (Universidad de Buenos Aires) dentro del marco del Proyecto "Poéticas y estéticas contrahegemónicas del videoarte y el cine-ensayo", dirigido por Clara Kriger y David Oubiña. Asimismo, el trabajo está articulado dentro del Proyecto de Investigación Estéticas Subalternas y Artivismos Contrahegemónicos de la Escuela Superior Politécnica del Litoral (ESPOL), del cual soy Investigador Principal (IP).z
} 


\section{The image-baroque. Introduction to the cinema of Andrés Di Tella}

\begin{abstract}
This article focuses on the study of the creation tactics of the Argentine documentary filmmaker Andrés Di Tella. These tactics have in common the deviant reading of visual archives adopting elements of collage, ready-made and found footage. The methodology proposed establishes the processes of inter-breeding and hybridization of Latin American and European Baroque as a frame of reference in order to determine the modes of folding and synthesis that operate in his films. Thus, the results of this research reveal how the tactics of each Di Tella film the reconstruction of the reconstruction in Reconstruyen crimen de la modelo (1990), the history of history in Montoneros, una historia (1995), the art of the art in Macedonio Fernández (1995), the image of the no image in La televisión y yo (2002), the otherness of the self in Fotografías (2007), the file of the file in El país del diablo (2008), all the images in Hachazos (2011), and all the words in 327 cuadernos (2015) - are constructed from a plurality of appropriation and recontextualization strategies that reveal a multiplicity of ways to express what we have called the image-baroque.
\end{abstract}

Key words:

Audiovisual archives, Baroque, Documentary film, Aesthetic hybridizations, Fold. 


\section{Introducción}

Juan Ancha sostiene que los latinoamericanos "somos plurales, en tanto nacemos y crecemos rodeados de las diferencias más opuestas, nos nutren varios mestizajes y podemos adoptar indistintamente varias maneras de ser" (citado en Flores Ballesteros, 2003, p. 34). Lo latinoamericano, por tanto, no conforma una esencia terminada, clausurada y estática, por el contrario, se manifiesta como un magma plural, dinámico y diferencial: como la síntesis ontológica disyuntiva entre Europa y los pueblos precolombinos.

Ahora bien, es oportuno señalar que en el interior de este dinamismo ontológico mestizo nace una estética necesariamente híbrida: una estética que es la expresión de las cuestiones étnicas que se manifiestan en lo mestizo (Schwartz, 1983, p. 14), una estética que supone un trabajo de mixturas y de apropiaciones; de traducciones y recontextualizaciones de otros saberes, en una suerte de "reacomodo epistemológico" (Rodríguez-Plaza, 2005, p. 112). Por consiguiente, las síntesis disyuntivas a nivel ontológico en América Latina, a través del mestizaje, tienen su reflejo y su efecto lógico en las hibridaciones y mixturas estéticas.

Para dar cuenta de la ligazón entre ambos procesos —ontológicos y estéticoscaracterísticos de la creación latinoamericana, hemos tomado como objeto de estudio la obra del documentalista argentino Andrés Di Tella: una obra fuertemente marcada por el uso de mecanismos autorreferenciales y biográficos. Paulo Antonio Paranagua (2003), en Cine Documental en América Latina, lo destaca entre los 15 documentalistas más significativos del continente. En 2008, se realizaron retrospectivas de su obra en la Filmoteca Española de Madrid y en la Filmoteca de Catalunya de Barcelona. Hizo periodismo en los periódicos The Buenos Aires Herald, Tiempo Argentino, La Razón y Río Negro y en Radio Nacional. Fue el fundador y primer director del Buenos Aires Festival 
Internacional de Cine Independiente (BAFICI), creado en 1999 y considerado uno de los eventos cinematográficos más importantes de América Latina. Desde 2002, dirige el Princeton Documentary Festival, en la Universidad de Princeton, Estados Unidos, donde ha sido Visiting Professor. Integra el Consejo de Dirección de la Universidad Torcuato Di Tella, donde impulsó la creación del Programa de Cine y donde también enseña (Fundación Konex, 2011). Su última película, Ficción privada (2019), se estrenó en el Festival de Cine de San Sebastián.

\section{Método}

Analizar, valorar e interpretar las películas documentales de Di Tella sería una empresa de largo alcance y, por ello, abordarla sería más propio de una tesis doctoral que de un artículo de investigación. Por este motivo, en lo que sigue, no pretendemos profundizar en el análisis de cada película, sino que más bien pretendemos abstraer la esencia de su mecanismo táctico, entender las estratagemas de creación que el cineasta desarrolla a lo largo de su variada, pero a la vez, coherente obra. Se trata de registrar esos gestos nucleares que determinan la táctica de cada obra. Desde su primer vídeo, realizado junto con su amigo Fabián Hofman, Reconstruyen crimen de la modelo (1990), hasta su último trabajo Ficción privada (2019), Andrés Di Tella ha adoptado, como táctica fundamental, el remontaje de archivos por medio del comentario en primera persona. Es decir, su forma de trabajar consiste en la lectura desviada de archivos: toda una pragmática hermenéutica ligada a las técnicas del collage, del ready-made y del found footage.

Ahora bien, estas relecturas del archivo tienen una fuerte conexión y vinculación con uno de los núcleos de creación más significativos del arte latinoamericano: el barroco. Nuestro objetivo, por tanto, consiste en explicar las tácticas de relectura del archivo que moviliza Di Tella dentro del contexto 
onto-estético de las pluralidades, hibridaciones y mestizajes del barroco latinoamericano. Apuntemos que el barroco latinoamericano ha importado un modo de eurocéntrico que es reapropiado y transmutado con el fin de reescribir y poner en cuestión los lindes de su identidad (Marín, 2020), dando lugar a una relectura que supone una estrategia de teatralización del mundo que trasciende la realidad (Álvarez Solís, 2017).

Asimismo, nos apropiaremos de conceptos del barroco europeo puesto en escena en las obras de Gottfried Wilhelm Leibniz y de Baruch Spinoza. Como vamos a tratar de demostrar, las tácticas de creación de Di Tella acogen elementos del barroco, pero sobre todo dos ideas vinculadas entre sí: la idea de síntesis de diferencias y la idea de pliegue. Gilles Deleuze (1989), en El pliegue. Leibniz y el barroco, afirma que el barroco no inventa nada. O, para ser más precisos, inventa una nueva forma de relacionar las formas anteriores, una suerte de síntesis heterogénea y de hibridación de los estilos anteriores: lo romano, lo griego, lo gótico. Estas síntesis son igualmente pliegues. Como afirma Deleuze, "siempre hay un pliegue en el pliegue, como también hay una caverna en la caverna. La unidad de materia, el más pequeño elemento de laberinto es el pliegue" (1989, p. 14). Así, la idea de barroco, sostenida por los conceptos de síntesis de diferencias, de pliegue sobre pliegue y de organismos dentro de organismos articula con las tácticas de creación de Di Tella, a saber: la reconstrucción de la reconstrucción en Reconstruyen crimen de la modelo (1990); la historia de la historia en Montoneros, una historia (1995); el arte del arte en Macedonio Fernández (1995); la imagen de la no-imagen en La televisión y yo (2002); la otredad del yo en Fotografías (2007); el archivo del archivo en El país del diablo (2008); la totalidad de las imágenes en Hachazos (2011) y la totalidad de palabras en 327 cuadernos (2015). 
Dejemos claro, en primer lugar, que estas tácticas de creación son abstracciones en dos sentidos. Son abstracciones conceptuales que apuntan a la determinación sintética de cada estrategia y, por este motivo, no resulta imprescindible la lectura analítica, sistemática y detallada. En segundo lugar, estas tácticas no suponen una reconstrucción del trabajo creativo del cineasta y, por ello, no consideramos relevante arrojar luz sobre sus procesos productivos. Más bien, las tácticas creativas son abstracciones hermenéuticas que hemos forjado con el fin de entender: a) el modo en que cada una de ellas se articula con los mecanismos del barroco - expuesto en los resultadosy b) el modo en que todas ellas se articulan para expresar el concepto de imagen-barroco - expuesto en la conclusión.

\section{Resultados}

A continuación vamos a valorar, en orden cronológico, los diversos pliegues o síntesis de diferencias de raigambre barroca que operan en algunas de las películas más representativas de Andrés Di Tella, con el fin de configurar lo que vamos a llamar la imagen-barroco. A pesar de que podría resultar poco original, el orden cronológico de los resultados nos aporta un elemento genealógico pertinente y relevante, dado que nos sirve para vislumbrar cómo cada una de las nuevas tácticas de creación emerge de la anterior. Por ello, aunque la praxis cronológica pueda adolecer de cierto didactismo, en nuestro caso, se releva como un articulador argumental.

\section{La reconstrucción de la reconstrucción en Reconstruyen crimen de la modelo (1990)}

En Reconstruyen crimen de la modelo (1990), la táctica barroca de creación consiste en una forma especial de pliegue: la reconstrucción de la reconstrucción. En esta pieza de carácter experimental, Andrés Di Tella y 
Fabián Hofman, se apropian de un fragmento de un noticiero que reconstruye el crimen de una modelo y lo reeditan y manipulan, dando pie a un sostenido extrañamiento por medio de la ralentización de la imagen, el silencio y la inclusión de imágenes en negro a modo de contrapunto.

De este modo, el film se estructura como "una reconstrucción de la reconstrucción" (Taquini, 2008, p. 39), como una narración donde "el vídeo resulta de un relato construido sobre la versión televisiva de la puesta en escena del crimen generada a partir del testimonio de uno de los implicados en el asesinato" (Denegri, 2008, p. 187). Esta mise en abyme se construye, por tanto, en tres niveles ontológicos. En primer lugar, tenemos la reconstrucción teatral del crimen. En segundo lugar, la reconstrucción del registro de dicha reconstrucción. Y, finalmente, en tercer lugar, la reconstrucción de la reconstrucción del registro de la reconstrucción teatral por medio de las detenciones temporales y de las pautas rítmicas de la pantalla en negro.

Igualmente, hay que señalar que esta reconstrucción de la reconstrucción implica una reconfiguración imaginaria de lo real. El film elabora una reflexión sobre los modos de construcción de los acontecimientos en el ámbito televisivo, esto es, sobre los modos de ficcionalización de lo real. Una de las referencias teóricas para elaborar este vídeo, que el propio Di Tella confiesa, es el texto Construir el acontecimiento de Eliseo Verón, donde el pensador argentino sostiene la hipótesis de que la realidad solo existe por los medios informativos (1984, p. 57). Esto es, los medios de comunicación son máquinas de producción del acontecimiento y la acción de reconstruir un hecho, por medio de la recreación o la reconstrucción, supone la ficcionalización y teatralización de lo real.

Esta síntesis disyuntiva de lo real y lo ficcional guarda una fuerte filiación con la idea latinoamericana de lo real-maravilloso. Este proceso de reconstrucción de 
la reconstrucción, que posibilita el pliegue de lo real y lo imaginario, conforma una imagen-barroco: un barroquismo que produce la imagen de una imagen, ejemplificando, de forma literal, los caracteres de la mónada leibniziana, que plegan organismos dentro de organismos. Para el filósofo alemán, las mónadas interpretan todo el universo desde su perspectiva. De igual modo, estos plegamientos de lo real-ficcional son la expresión de una de las fórmulas egregias del barroco latinoamericano, a saber, la fórmula de Alejo Carpentier: "toda simbiosis, todo mestizaje, engendra un barroquismo" (1984, p. 119). Di Tella parece adoptar, en esta pieza de found footage, una estrategia cercana tanto a la filosofía barroca de Leibniz — la película como reconstrucción de una reconstrucción- como al espíritu del barroco latinoamericano - la película como la síntesis de lo real y lo imaginario.

\section{La historia de la historia en Montoneros, una historia (1995)}

Montoneros, una historia (1995) también se construye de forma barroca, ya que la estructura del documental privilegia una perspectiva singular y determinada -igual que las mónadas de Leibniz- a través de la historia de Ana, una militante de los montoneros. Di Tella presenta así una de las historias posibles para articular toda una historia colectiva. Si en el film anterior Di Tella plantea la táctica de la reconstrucción de la reconstrucción; en Montoneros, una historia, la táctica utilizada es la de subrayar una historia dentro de una historia.

Se puede observar cómo la estructura del documental muestra una manera de ser: la perspectiva singular de Ana dentro de un magma sociopolítico más complejo. Ahora bien, la perspectiva de Ana se intersecta con otras perspectivas: con las otras maneras de ser de los otros militantes montoneros, que también aparecen en la película en un esfuerzo por dilucidar las contradicciones de la lucha armada. David Oubiña da en la clave del perspectivismo cuasi-leibniziano cuando sostiene que "a través del testimonio de la 
protagonista, su familia, sus excompañeros y los dirigentes de la agrupación peronista Montoneros, la película cuenta una de las muchas historias y lo hace desde una de las perspectivas posibles" (2004, p. 71). La película presenta fragmentos de archivo sobre la lucha de los montoneros, que se van entrelazando con la visión de Ana en diálogo con la visión de otros compañeros montoneros - como Jorge Rullii, Roberto Perdía, Domingo Godoy, Jorge Falcone, Graciela Daleo, entre otros-. Todos ellos inician una reflexión moral sobre su lucha, centralizando parte de dicha reflexión en la violencia. Ana se muestra crítica con el pasado y su visión es a veces compartida, y a veces no, por el resto de compañeros de militancia. Pero lo significativo de este film es que Di Tella no despliega su mirada subjetiva, como hará en el resto de su obra, sino que presenta los testimonios en su diversidad perspectivista, propiciando diversos encuentros, conflictivos o conciliadores, con el testimonio de Ana (Álvarez, 2012).

Ahí, justamente, radica el barroquismo del documental: se trata de construir los pliegues de la historia y, por ello, de reflejar y expresar la historia de los montoneros. Esto es: lo social a partir de una historia individual. El documental va a erigirse como una historia de la historia de los montoneros, adoptando una lógica que va de lo singular a lo común. En el film resuenan, igualmente, los acordes de la filosofía barroca de Baruch Spinoza (2009), que sostiene que el sujeto es la expresión posible de la substancia inmanente única y necesaria. La historia de Ana es una manera de ser de la historia de los montoneros. O, por decirlo con la jerga spinozista, Ana es una composición interna de la sustancia del movimiento montonero, una manera de ser que expresa una concreción y una singularidad, una manera individual de ser en el ser de lo social que se relaciona con las otras maneras de ser. Toni Negri considera que el pensamiento de Spinoza es un pensamiento de la potencia ontológica que determina el poder constituyente: "La inmanencia spinoziana de lo colectivo es constituyente a través de los conflictos de las singularidades" 
(2014, p. 101). A la luz de la lectura política del spinozismo podemos afirmar que la singularidad de Ana, en contraste con las demás singularidades, expresa lo colectivo. Por ejemplo, en la secuencia de la parte final de la película, donde aparece revisando una serie de documentos y archivos de la organización, de lo colectivo, y va describiéndolos y comentándolos desde su perspectiva. Sin duda, este dispositivo metadiscursivo es propio de la praxis barroca: desde una historia cristalizada en un archivo - que no es otra cosa que la certificación de un tiempo pasado - se va forjando otra historia — desviada, subjetiva y vivencial— por la vía del comentario.

\section{El arte del arte en Macedonio Fernández (1995)}

Hay dos tácticas de creación que nos permiten evaluar el documental Macedonio Fernández (1995) desde las coordenadas del barroco: la síntesis de diferencias artísticas y el trabajo de relectura subjetiva del ensayo.

Respecto a las síntesis de las diferencias artísticas, hay que apuntar que el film se construye a partir de la suma de diversos pliegues y perspectivas, leivmotiv recurrente de la lógica del barroco. El dispositivo del film se sostiene gracias a la evocación que el escritor argentino Ricardo Piglia hace de la figura de otro escritor argentino: Macedonio Fernández. La película guarda cierta filiación con Reconstruyen crimen de la modelo y con sus sistema de reconstrucciones: la película es el resultado de la perspectiva artística que tiene el cineasta Andrés Di Tella de la perspectiva artística que Piglia tiene de la perspectiva artística de Macedonio Fernández. Sin embargo, este dispositivo metadocumental se redobla cuando el cineasta introduce en su película —en su obra de arteuna multiplicidad de evocaciones y representaciones artísticas en torno a la obra de Macedonio Fernández. La película comienza con Ricardo Piglia relatando la experiencia de escribir una novela, La ciudad ausente, inspirada en Macedonio Fernández. Asimismo, a lo largo de la película se muestra la 
obra de Macedonio Fernández en tanto germen de otras obras: de la ópera Macedonio en fa menor, donde se relata como Macedonio construye una máquina para perpetuar el alma de su mujer que se está muriendo; de una película sobre Macedonio; de la videoinstalación de Roberto Jacobi y de las esculturas de Carlos Boccardo. Todas estas relecturas de la obra de Macedonio Fernández son registradas por el cineasta y puestas en relación para forjar un sistema de evocaciones singulares sobre la figura de Macedonio Fernández. Se trata de mostrar en el interior del arte del cine las perspectivas sobre el arte de la literatura, de la música, de la videoinstalación y de la escultura. El arte del arte por medio de relecturas y reinterpretaciones que se van entretejiendo con maestría artística y rigor investigativo, forjando así una compleja materia intertextual. El documental encarna la idea barthesiana de la intertextualidad — una idea ligada al barroco- de que todo texto es un intertexto y, por tanto, es la cita de los textos escritos en el pasado, a la vez que hace resonar la idea del barroco Carpentier: toda simbiosis implica barroquismo. $\mathrm{O}$, en el lenguaje de Leibniz: el documental es una mónada-arte que interpreta el resto del universo-arte.

Además del complejo sistema intertextual, es interesante mostrar cómo en el documental se ejerce un trabajo de reconfiguración subjetiva de los materiales, subvirtiendo de este modo la praxis hegemónica de la objetividad documental. Para Di Tella, el documental solo puede entenderse desde la óptica de la subjetividad, del enfoque de la primera persona. Este mestizaje de la subjetividad que reinterpreta lo objetivo del mundo, aparece evocado en la videoinstalación de Roberto Jacobi, donde hay un magnetófono que hace resonar las palabras de Macedonio: "no he visto nunca un yo que naciendo se encontrara sin mundo". Indudablemente, la cita es una síntesis preclara de la forma subjetiva del ensayo, de la síntesis entre lo subjetivo y lo objetivo, que conecta con las formas del barroco que van del mundo al 
individuo y viceversa: de la sustancia a la manera en Spinoza y de la mónada al mundo en Leibniz.

Al final del documental, aparece la referencia a la idea de Macedonio sobre la novela futura, que será la suma de todas las formas, de todos los pliegues, de todas las artes: será diario, ensayo, historia del arte, cuento. Esta función sintética y englobadora de diferencias genéricas de la literatura es inequívocamente barroca, y parece redoblar y subrayar el sistema de pliegues entre las artes que se manifiesta en el documental. Tanto el pliegue de todas las artes como la diferencial subjetividad/objetividad son caracteres barrocos. Octavio Paz escribe sobre la poesía barroca de Sor Juana Inés de la Cruz que

no sólo usa admirablemente el habla popular de mulatos y criollos, sino que incorpora la lengua misma de los Indios, el náhuatl. No le mueve un nacionalismo poético sino todo lo contrario: una estética universalista que se complace en recoger todos los pintoresquismos y hace brillar todos los particularismos. (2014, p. 21)

Lo mismo que Di Tella en este documental: recoge los particularismos de cada arte y los expresa a través del cine.

\section{La imagen de la no-imagen en La televisión y yo (2002)}

Del documental La televisión y yo (2002) vamos a destacar tres tácticas que permiten la forja de una imagen-barroco: la producción de la imagen de la no-imagen, el delirio de las asociaciones libres y el carácter metadocumental del fracaso del film previsto por el autor.

Como hemos mostrado hasta ahora, las tácticas barrocas de Di Tella se caracterizan por su fuerza de plegamiento: la reconstrucción de la reconstrucción, la historia de la historia, el arte del arte. En esta praxis del plegamiento faltaría uno de los estilemas que caracteriza al barroco: el 
uso de imágenes dentro de imágenes. Sabemos que para que este uso sea posible, tiene que darse cierta distancia respecto a la imagen utilizada: algo así como la conciencia de que una imagen es algo que ya ha entrado en el devenir de la historia y, por tanto, puede reutilizarse en otros contextos. Sin embargo, lo interesante de la táctica que despliega Di Tella radica en el uso de medios visuales para hablar de la falta de imágenes. El documental se sostiene sobre una singular experiencia biográfica del autor, a saber, que su infancia transcurrió fuera de Argentina y, por ello, no pudo asimilar la cultura televisiva de su época. Su padre, profesor de sociología en la Universidad de Buenos Aires, renuncia a su cátedra y marcha a Estados Unidos con su familia. Sobre imágenes del exilio familiar relata: "Me perdí siete años de televisión. La mitad de los recuerdos de mi generación no los vi. Cuando mis amigos hablan de la televisión no recuerdo nada". La película, por tanto, se construye como la imagen de la falta de imágenes, como la imagen de la no-imagen, como la imagen de una segunda vida forjada en el imaginario por la televisión. Di Tella siente que parte de su vida está vacía: un fragmento de su identidad ha desaparecido, haciéndolo dudar inclusive de su condición de argentino.

La anterior afirmación es el detonante para realizar un trabajo arqueológico de la existencia de la televisión en los archivos de la Biblioteca Nacional. Pero, justo en ese momento, el relato empieza a delirar y a realizar asociaciones libres: la búsqueda le lleva a entrar en contacto con Sebastián Yankelevic, el nieto de Jaime Yankelevich, introductor de la televisión en Argentina, para terminar el complejo periplo investigativo en una conversación con su padre, que le cuenta la historia de su propio abuelo, Torcuato Di Tella, dueño de un imperio industrial en la misma época. El film se tiñe todavía más de elementos confesionales e íntimos al introducir en la imagen a su propia familia, construyendo, de este modo, una trabada trama barroca. Deleuze afirma que en el barroco "el punto de vista sobre una variación sustituye al centro de una figura o de una configuración" (1989, p. 32). Esta idea puede trasponerse a 
la poética del film: narrar desde un punto de vista, el del autor, la universal variación de lo real, donde no hay centro y donde los ejes de coordenadas se disuelven.

Por último, hay que apuntar que el film desemboca en un fracaso: no hay recuerdos de esas imágenes que construyen una segunda vida. El propio Di Tella narra al inicio del documental dicho fracaso: "quería hacer una película sobre la televisión. Pero me salió otra cosa, lo que quedó fueron notas en una libreta. La televisión y yo. Notas en una libreta". Y, en el cierre, la siguiente reflexión en off en contraste con las imágenes de su familia: "A lo mejor esta película era un pretexto para hablar con mi padre (...) Creo que me equivoqué de proyecto. Ahora esos fotogramas de televisión antiguos no me dicen nada. Lo que se perdió, se perdió". Parece pues que, finalmente, el film narra la pérdida de las imágenes de televisión de la infancia a través de imágenes de archivos familiares en un esfuerzo de reconstrucción identitaria a través del diálogo paterno.

Pero no solo eso: el documental es simbiosis y mestizaje carpentieriano de documental, televisión, historia, ensayo, autobiografía, cuento plasmando así las síntesis de la novela futura según Macedonio Fernández. En definitiva, el documental como una ecuación diferencial de todos los estilos al modo barroco.

\section{La otredad del yo en Fotografías (2007)}

Si La televisión y yo es una excusa para hablar con su padre, Fotografías (2007) es una excusa para viajar a la India en busca de las raíces familiares de su madre. El film muestra cómo la mirada sobre la vida de su madre es el camino hacia el encuentro con su propia identidad. El documental muestra cómo esa otredad hindú es la mitad constitutiva de su identidad: lo otro de su yo, el "yo 
es otro" de Arthur Rimbaud, Jean Rouch o Gilles Deleuze. En otras palabras, la praxis de esa otredad del yo es algo netamente barroco: son los pliegues identitarios de lo uno y de lo otro, del acá argentino y el allá indio.

En el inicio de Fotografías, el cineasta aparece comentando una serie de fotografías de su viaje a la India cuando tenía once años. En una de las imágenes, en diálogo con una amiga, ésta corrobora el parecido físico con su madre. Esa similitud fenotípica es la que proyecta hacia adelante el relato, un relato cuya finalidad no es otra que la búsqueda de la identidad. Y es, justamente, esa identidad mestiza e híbrida, la que es reconocida por Di Tella cuando, antes de iniciar su viaje, afirma: "Soy un cruza". Dicha afirmación pone de manifiesto la diferencial ontológica constituyente de su subjetividad, esto es, la idea barroca de que todo ser está conformado por otros seres diferenciales: los seres dentro de seres al modo de la Monadología de Leibniz. Son tácticas donde la relación identidad-alteridad solo puede leerse en tanto intensidades proclives a la descomposición y la recomposición; al devoramiento y la metamorfosis (Rossi, 2018).

Secuencias más tarde, vemos al director junto a su padre comentado imágenes familiares y discutiendo sobre los diversos problemas de una pareja interracial. Problemas que, en parte, forzaron a su madre no solo a renegar de su identidad hindú, sino también a bloquear toda transmisión cultural a sus hijos. Esta pérdida, sin duda, es más profunda que los siete años sin televisión de La televisión y yo, pérdida identitaria que le lleva a afirmar "porque yo era hindú. Pero yo no era hindú. En el espejo podía ver el hindú que veían los otros", pérdida que es el detonante de su viaje, un viaje que le catapulta a sumergirse en las profundidades de la vida de su madre a través de los relatos y las fotografías de sus parientes hindúes, y que concluye con la siguiente confesión: "No puedo dejar de pensar que es de esta familia de la que mamá quiso escapar (...) 
Deseo de quitarse de encima el peso de la identidad, la familia, la sangre, la raza, la nacionalidad. Pensarlo me da una extraña emoción".

A pesar de que el mestizaje de Di Tella no es la expresión de la síntesis racial entre los europeos y los indígenas de la América precolombina, es relevante señalar que el mestizaje es un factor determinante en la configuración de la estética postcolonial latinoamericana. La transculturación favorece el carácter simbiótico del barroco. Carmen Bustillo (1988) asegura que el mestizaje racial, cultural y lingüístico de dos mundos es un factor determinante, ya que permite la incorporación de otros materiales heterogéneos. En este punto, sería interesante apuntar cómo la hibridación ontológica de Di Tella se proyecta sobre la praxis sintética de su estética: cómo la diferencial ontológica resuena en la diferencial entre el documento y la subjetividad que jalona su filmografía. Es en todo punto manifiesto que el mestizaje favorece la construcción del barroco, pues permite la interacción entre elementos opuestos. Toda mezcla, toda hibridación racial y cultural encierra en su interior una pulsión barroca y postcolonial. La consecuencia inmediata de este proceso de mestizaje, de estas síntesis heterogéneas, es la pérdida de centro. En todo el cine de Di Tella se manifiesta una ausencia de centro: en su cine se instala un sentimiento de pérdida identitaria, de descentramiento, y de vértigo que articula con la esencia barroca. Lo que se afirma sobre el barroco latinoamericano bien se puede afirmar del cine de Di Tella: el arte de Di Tella es la expresión de la carencia de centro de la identidad como quehacer de la imagen-barroco.

\section{El archivo del archivo en El país del diablo (2008)}

Si Fotografías (2007) desarrolla la táctica de la otredad del yo ligada a la reflexión en torno a la identidad postcolonial, El país del diablo (2008) dispone la táctica del archivo del archivo con una intencionalidad crítica con los procesos de colonización. Observamos como, en este documental, la forma de trabajar de 
Di Tella tiene un carácter autorreferencial, pues siempre asimila conceptos de procesos artísticos previos y los reevalúa desde otras coordenadas. Siempre se trata de síntesis y pliegues como expresión de la imagen-barroco.

La táctica de creación de El país del diablo consiste en crear un dispositivo donde el quehacer del objeto de estudio se traslada y proyecta hacia la metodología del sujeto de la investigación. Es decir, Di Tella va a trabajar de modo similar a Estanislao Zeballos, el escritor al que consagra este trabajo. En el documental, se relata cómo Zeballos fue el primer blanco que se interesó por las culturas indígenas exterminadas en la Conquista del Desierto a finales del siglo XIX, lo que le permitió descubrir el archivo de cacique Namuncurá. Este archivo conservaba la memoria de un pueblo aniquilado. En una de las secuencias, mientras observa las cartas del cacique Namuncurá, Di Tella reconoce: "Zeballos es una especie de documentalista como yo". De este modo, se establece una transferencia empática y creativa que determina la forma del documental como un archivo de un archivo. O lo que es lo mismo: un meta-archivo

Aparte de las cartas, el documental va interpretando y resignificando los diversos documentos que fue atesorando Zeballos: dibujos sobre astronomía indígena, mapas, una colección de cráneos, imágenes de los últimos rastros visibles de la frontera con el indio. A esta última cuestión de la frontera le dedica bastante atención, entendido la historia de la frontera como una historia de las negociaciones. Una negociación que conecta con la idea de frontera de Jean-Luc Godard en tanto intersticio entre la imagen y el sonido; y entre la realidad y la ficción. Así, podemos afirmar que la idea geopolítica de frontera se transfiere al dispositivo estético, a la frontera entre lo real y lo ficticio. De hecho, en la secuencia inmediatamente posterior, el cineasta argentino realiza una relación diferencial entre la representación de un paisaje de la guerra y el lugar real donde acontecieron los sucesos, determinando así el nexo fronterizo entre la representación y la realidad. 
Por otro lado, cabe señalar que el más relevante de todos los archivos es la colección de ciento cincuenta cráneos indígenas. Esta colección de cráneos tenía para Zeballos una funcionalidad científica. Al final del documental, Di Tella conversa con un señor que enseña el lenguaje y las costumbres de los indígenas, en un esfuerzo por conservar el fino hilo de memoria, por resistir al olvido. Una memoria conservada en las imágenes de los supervivientes de la conquista, como sus nombres y apellidos. El número de imágenes es ciento cincuenta. El mismo número que la colección de cráneos.

En conclusión, el archivo de Zeballos es rearchivado por Di Tella en un meta-archivo o archivo del archivo, que supone un esfuerzo de conservación de la memoria. Ahora bien, este esfuerzo supone un acto de resistencia propio del barroco: a pesar de ser una imposición cultural exógena y colonial, el barroco "los americanos lo convirtieron en un instrumento para manifestar su propia identidad cultural" (Lezama Lima, 1988, p. 230). En este sentido, el barroco no deja de desterritorializar la cultura impuesta a través de la cultura propia, enmascarándola estratégicamente: es la manifestación de la cultura autóctona desde las formas de la cultura dominante. Todo un efecto de contraconquista. Di Tella hace algo parecido con los archivos de Zeballos: los desterriroriliza, los resignifica, los repliega y rearchiva. El barroco de Di Tella supone una praxis de la reconfiguración de los archivos de la conquista y la escenificación de un arte de la contraconquista: una contravisualidad frente a la visualidad hegemónica.

\section{Todas las imágenes en una maleta en Hachazos (2011)}

Hachazos (2011) comienza con la siguiente alocución:

Un hombre lleva toda su obra, que es toda su vida, dentro de una vieja valijita de cuero comprada en la India, en un tren que va de Moreno a General Rodríguez, por el conurbano bonaerense. Son los originales de sus películas, todas en super-8, un formato en vías de extinción, que no permite copias. 
Esa valija es como el manuscrito de su autobiografía. Se trata de Claudio Caldini, cuidador de una quinta de los suburbios, cineasta secreto.

Queda claro que las películas de Claudio Caldini son su vida: "una vida de imágenes encerrada en una maleta" escribe Di Tella en uno de sus cuadernos. Una maleta como el lugar de todas las imágenes de una vida: imágenes dentro de imágenes, imágenes entre imágenes. Y esto, nuevamente, es la expresión de la esencia del barroco donde, una vez más, la filosofía de Leibniz resuena. En el parágrafo 67 de su Monadología escribe: "Cada porción de la materia puede ser concebida como un jardín lleno de plantas; y como un estanque Ileno de peces. Pero cada ramo de la planta, cada miembro del animal, cada gota de sus humores es, a su vez, un jardín o un estanque semejante" (Leibniz, 2001, p. 18). Y eso es, justamente, la maleta de Claudio Caldini: el signo de la vida de un ser humano lleno de imágenes. Pero también, el signo de unas imágenes que contienen al ser humano. Síntesis y pliegue de imágenes y seres.

La historia de Hachazos es - entre otras cosas - la historia de las estrategias de creación de Claudio Caldini. Di Tella, apelando de modo patente a Reconstrucción del crimen de la modelo, aborda en el film la reconstrucción de los modos de creación de Caldini. Una reconstrucción forjada a partir de dos movimientos. En el primer movimiento, Di Tella registra los hilos de la marioneta, el dispositivo, la forma de la táctica que está detrás de las imágenes. Mientras que, en un segundo movimiento, registra el resultado: la materia de la creación. De este modo, en las dos primeras reconstrucciones, observamos como Caldini ata una cuerda a la parte superior de la cámara y realiza diversos movimientos con ella. En la primera reconstrucción, tuerce la cuerda; en la segunda, gira la cuerda sobre su eje. Y, acto seguido, se muestra el resultado del experimento. 
Podemos interpretar estas reconstrucciones de las imágenes del mundo de Caldini como la relación barroca entre el mundo y el sujeto. El sujeto capta el mundo en universal variación desde su perspectiva singular. El mundo "es la curva infinita que toca en una infinidad de puntos una infinidad de curvas, la curva de variable única, la serie convergente de todas las series" (Deleuze, 1989 , p. 37); mientras que el sujeto es la "unidad individual que expresa el mundo entero, pero no lo expresa sin expresar más claramente una pequeña región del mundo, un departamento, un barrio de la ciudad, una secuencia finita" (Deleuze, 1989, p. 38). En este sentido, Hachazos funciona como la ontología leibniziana. Muestra el mundo expresado desde la óptica del sujeto: primero el mundo (primer movimiento), y luego el mundo desde la manera y la perspectiva del sujeto (segundo movimiento).

\section{Todas las palabras en unos cuadernos en 327 cuadernos (2015)}

Si Hachazos narra la vida de un hombre que guarda todas sus imágenes en una maleta, 327 cuadernos es la historia de un hombre que guarda todas sus palabras en 327 cuadernos. Este hombre es el escritor Ricardo Piglia, que ya colaboró en el documental Macedonio Fernández.

Al inicio del documental, vemos a Piglia recogiendo sus pertenencias en su despacho de la Universidad de Princeton para poner rumbo a Buenos Aires y así poder leer los 327 cuadernos que componen su diario. La película de Di Tella va a consistir en mostrar "el proceso de hacer un diario de la lectura de un diario". Esto es, construir un meta-diario cuya forma estructural, nuevamente, es la de la mónada, la síntesis y el pliegue. En las primeras imágenes de los diarios afirma Piglia: "Tengo la sensación de haber vivido dos vidas. La mía y la de los cuadernos. Existen en el diario, pero no en el recuerdo". Nuevamente una alusión a una película anterior, en este caso, a la segunda vida de la televisión en La televisión y yo. 
La idea de meta-diario de 327 cuadernos configura una nueva modalidad de imagen-barroco que remite a las praxis del barroco español: a la meta-metáfora y a la meta-imagen. Dentro del ámbito de la literatura del barroco español destaca la figura de Luis de Góngora, que no trabaja ni con el lenguaje hablado ni con el lenguaje literario, sino que lo hace con la metáfora de las metáforas de esos lenguajes (Paz, 2014, p. 21). Esto es, una meta-metáfora. El carácter meta de la obra de Di Tella también remite al sistema de meta-imágenes adoptado por el pintor español Diego Velázquez. Sabemos que en Las Meninas se despliega toda praxis de imágenes dentro de imágenes que hacen del cuadro una complicada meta-imagen: las imágenes de cuadros, la imagen especular de los reyes, la imagen-revés del bastidor e incluso la falsa imagen del personaje que está a punto de abandonar la escena y que aparece recuadrado por la luz que atraviesa la puerta del fondo de la sala.

Hay que señalar, por último, que el meta-diario también remite a la idea de ethos barroco latinoamericano, formulada por Bolívar Echeverría. Para el filósofo ecuatoriano el barroco es "un principio de construcción del mundo de la vida" (Echeverría, 2011, p. 37) y, por ello, el barroco va más allá de la mera decoración y deviene puesta en escena que sustituye a la vida dentro de la vida. Para Echeverría el ethos barroco es la fidelidad al carácter cualitativo de la vida y, en este sentido, podemos atrevernos a definir 327 cuadernos como el barroquismo del diario del diario que representa la vida.

\section{Conclusiones}

En la presente investigación nos hemos esforzado en mostrar cómo la obra de Andrés Di Tella se construye a partir de una pluralidad de tácticas de apropiación y recontextualización de imágenes de archivo. Estas tácticas de desvío y alteración del archivo, en tanto que resto de una perspectiva del tiempo pasado, guarda una relación genética con el barroco y con su lógica de las 
hibridaciones y los mestizajes. Por tanto, partiendo de las conceptualizaciones del barroco latinoamericano y europeo, en especial desde las coordenadas trazadas por la Monadología de Leibniz y por la Ética de Spinoza, hemos reconstruido la obra de Di Tella como un sistema de síntesis de diferencias y de pliegues de archivos diversos.

Cada una de estas tácticas es una expresión o manera, al modo spinozista, de la imagen-barroco. Y, por ello, a pesar de sus diversidades — unas veces plegan lo real y lo maravilloso; otras intersectan perspectivas plurales y maneras de ser; o manifiestan una pluralidad intertextual de configuraciones artísticas; o elaboran puntos de vista subjetivos sobre las variaciones del mundo; o forjan una diferencial ontológica entre lo uno y lo otro; o desterritorializan los archivos dominantes según procesos de contravisualidad; o propician la convergencia de todas las imágenes de la subjetividad en una maleta o todas las palabras en unos cuadernos - todos ellas funcionan por medio de plegamientos, síntesis, intersecciones, hibridaciones o mestizajes que expresan lo que hemos decidido denominar imagen-barroco.

En definitiva, todas estas tácticas, expresiones o maneras de la imagen-barroco determinan síntesis similares a las teorizadas en la antropofagia de Oswald de Andrade, donde la alteridad sirve para construir la identidad propia, esto es, donde la única alternativa para comprender al otro y para entrar en diálogo con sus singularidades y sus especificidades es devorándolo: "La vida es devoración pura" (1999, p. 26). 


\section{Referencias}

Álvarez Solís, Á. O. (2017). Barroco, casticismo, emancipación. En Rosas, L. F. B., \& Chávez, V. H. P., Confluencias barrocas (pp. 213-226). Leiden: Almenara.

Álvarez, V. (2012). "¿Habremos hecho bien?" Una aproximación a las zonas grises en Montoneros, una historia. Cine Documental, 5. http://revista. cinedocumental.com.ar/5/articulos_05.html

Bustillo, C. (1988). Barroco y América Latina. Un itinerario inconcluso. Caracas: Monte Ávila.

Carpentier, A. (1984). Lo barroco y lo real maravilloso. En Ensayos (pp. 119). La Habana: Letras Cubanas.

De Andrade, O. (1999). Manifesto antropófago. Nuevo Texto Crítico, 12, 25-31. https://www.redalyc.org/pdf/5521/552156376009.pdf

Deleuze, G. (1989). El Pliegue. Leibniz y el Barroco. Barcelona: Paidós.

Denegri, A. (2008). Del vídeo a la TV: la mirada crítica. Realizaciones videográficas argentinas relacionadas con el fenómeno televisivo. En J. La Ferla (comp.). Historia crítica del video argentino (pp. 181-198). Buenos Aires: Fundación Eduardo F. Constantini, Malba, Fundación Telefónica.

Echeverría, B. (2011). La modernidad de lo barroco. México D. F.: Ediciones Era.

Flores Ballesteros, E. (2003). Lo nacional, lo local, lo regional en el Arte Latinoamericano: de la modernidad a la globalización y la antiglobalización. Huellas. Búsquedas en Artes y Diseño. Revista, 3, 31-44. https://librosffyl.bdigital.uncu.edu.ar/objetos_ digitales/167/floresballHuellas3.pdf 
Fundación Konex. (2011). Andrés Di Tella. https://www.fundacionkonex.org/ b4363-andres-di-tella

Leibniz, G. W. (2001). Monadologia. Madrid: Biblioteca Nueva.

Lezama Lima, J. (1988). La curiosidad barroca. En Confluencias (pp. 230). La Habana: Letras Cubanas.

Marín, S. (2020). Breve acercamiento al barroco latinoamericano desde José Lezama Lima y Severo Sarduy. Versiones, 1(15), 85-92. https://revistas. udea.edu.co/index.php/versiones/article/view/344449

Negri, A. (2014). Biocapitalismo. Entre Spinoza y la constitución política del presente. Buenos Aires: Editorial Quadrata.

Oubiña, D. (2004). Cine y compromiso en la Argentina. En Sobre una realidad ineludible. Arte y compromiso en la Argentina. 1976-2001 (pp. 68-81). Valencia: Museo Extremeño e Iberoamericano de Arte Contemporáneo.

Paranaguá, P. A. (2003). Cine documental en América Latina. Madrid: Cátedra.

Paz, O. (2014). Sor Juana Inés de la Cruz o las trampas de la fe. Barcelona: Seix Barral.

Rodriguez-Plaza, P. (2005). Crítica, estética y mayorías latinoamericanas. Aisthesis: Revista chilena de investigaciones estéticas, 38, 99-120. http://revistaaisthesis.uc.cl/index.php/RAIT/article/view/4198

Rossi, M. J. (2018). Despliegue poscolonial y neobarroco latinoamericano: aportes para una hermenéutica de la contraconquista. Otros locos. Revista de Estudios Críticos, 52-68. http://www.ceapedi.com.ar/otroslogos/ Revistas/0010/05\%202019\%20Rossi.pdf

Schwartz, J. (1983). La vanguardia en América Latina: una estética comparada. Revista de la Universidad de México, 21, 12-16. https://anaforas.fic.edu.uy/ jspui/bitstream/123456789/11641/1/Schwartz.la.vanguardia.pdf 
Spinoza, B. (2009). Ética demostrada según el orden geométrico. Madrid: Tecnos

Taquini, G. (2008). Tiempos del vídeo argentino. En J. La Ferla (comp.). Historia crítica del vídeo argentino (pp. 25-48). Buenos Aires: Fundación Eduardo F. Constantini, Malba, Fundación Telefónica,.

Verón, E. (1984). Construir el acontecimiento. Barcelona: Editorial Gedisa.

Cómo citar: Bouhaben, M. A. (2021). La imagen-barroco. Introducción al cine de Andrés Di Tella. Revista KEPES, 18(23), 315-339. https://doi.org/10.17151/kepes.2021.18.23.11 